\title{
NÄKÖKULMIA \\ RUOTSIN AIKUISKOULUTUKSEN KEHITTÄMISTYÖSTÄ
}

\author{
Swedish National Board of Education \\ Adult Education in the 1990's: Considerations \\ and Proposals \\ Reports: Planning, Follow-up, Evaluation R 91:1 \\ Stockholm: Grafiska Gruppen 1991
}

Ruotsin kouluylihallitus, meidän opetushallitustamme vastaava keskusvirasto, on julkaissut kansainväliseen jakeluun englanninkielisen raportin "'1990-luvun aikuiskoulutus: näkökohtia ja ehdotuksia". Raportti on osa kouluylihallituksen KTS-esitystä kesältä 1990. Johdantosanojensa mukaan raportti heijastelee arvoja ja näkökulmia, joita Ruotsin poliittisessa keskustelussa nykyisin esiintyy pohdittaessa aikuiskoulutuksen ja oppimisen kehitystä jälkiteollisessa yhteiskunnassa.

Raportti jakautuu kolmeen osaan. Ensimmäinen osa, 'Kansalaisten oikeus tietoon ja omaohjauksiseen opiskeluun - haaste 1990-luvun aikuiskoulutukselle', käsittelee aikuiskoulutuksen kehittämiseen vaikuttavia yhteiskunnallisia muutoksia ja aatevirtauksia. Toinen osa, "Aikuiskoulutuksen osapuolet", kuvaa aikuiskoulutuksen eri muotojen ja järjestäjien työnjakoa Ruotsissa. Kolmas osa, "Aikuiskoulutuksen muutosstrategiat", sisältää esityksen laajaksi kehittämisohjelmaksi. Kuvaan seuraavassa lähemmin raportin ensimmäistä ja kolmatta osaa, jotka Suomesta katsoen tuntuvat mielenkiintoisimmilta.

\section{Kansalaisten oikeus tietoon ja omaohjauksiseen opiskeluun}

Raportti alkaa viittauksilla kouluylihallituksen teettämiin tutkimuksiin, joiden mukaan Ruotsin aikuisväestöllä on aikuiskoulutuksen aktiivisista ponnisteluista huolimatta edelleen merkittäviä puutteita koulutuksessaan ja tiedoissaan. Samalla todetaan, että koulutuserojen tasoittamiseksi ei enää tulevaisuudessa riitä kansakoulun käyneiden aikuisten koulutustason kohottaminen peruskoulun tasolle, kun valtaosa nuorista saa 11-12 vuoden koulutuksen.

180 Nämä kannanotot kuvaavat hyvin koko rapor- tin henkeä. Kaikki pohdinnat lähtevät pohjimmiltaan siitä, että aikuisten perustiedot ja -taidot on voitava saattaa ajan tasalle. Perusvalmiuksien sisältää etsitään toisaalta nuorten koulutuksen sisällöistä ja toisaalta aikuisten yhteiskunnallisen toiminnan ja muuttuvan työelämän asettamista vaatimuksista. Arvolähtökohdiksi esitetään solidaarisuus, oikeudenmukaisuus, demokratia ja kulttuuri.

Ruotsin ja englannin kielessä, matematiikassa ja yhteiskuntaopissa pidetään aikuisten perustietojen uutena tavoitetasona parin vuoden keskiasteen opintoja. Raportissa kiinnitetään huomiota myös siihen, että monilta yhdeksän vuoden koulutuksen käyneiltä aikuisilta tosiasiassa puuttuu osa tiedoista ja käsitteistä, joita oppivelvollisuusikäiset nykyään peruskoulussa oppivat.

Aikuiskoulutuksen kehittämiseen vaikuttaviksi yhteiskunnan ja työelämän muutoksiksi raportissa esitetään (1) tieto- ja informaatioyhteiskuntaan siirtyminen ja sen vaikutukset työn sisältöön, organisointiin ja taitovaatimuksiin, (2) henkilöstökoulutuksen nopea kasvu, joka osittain aiheutuu kasvaneista taitovaatimuksista, (3) väestön ikärakenteen muutos sekä (4) väestön koulutustason ja ammatillisen taitotason alueellisen epätasapainon kasvaminen.

Työelämän muutosten raportti arvioi johtavan siihen, että työvoiman koulutus tulee perustumaan aikaisempaa vähemmän työn ja koulutuksen vuorotteluun. Työtehtävistä ja työn organisoinnista tullaan muotoilemaan jo sinänsä kehittäviä, jolloin työstä irrottautumista ei enää entisessä määrin tarvita. Kun tällainen kehitys etenee, työpaikoilla pidetään arvossa hyvät perustiedot, vankan itseluottamuksen ja korkean opintojen omaohjauksisuusasteen omaavia aikuisia. Raportissa katsotaan, että julkisen aikuiskoulutuksen on kyettävä tuottamaan näitä valmiuksia, 
jotta työvoiman eri ryhmien valmiudet eivät pääse entisestään eriytymään.

Perimmältään taloudellisiin näkökohtiin perustuvan henkilöstökoulutuksen entistä suurempaa osuutta koko aikuiskoulutuksesta ja markkinavoimien voimistumista myös julkisesti tuetussa aikuiskoulutuksessa raportti pitää arvolähtökohtiensa mukaisesti monessa suhteessa vaarallisena ja vastatoimenpiteitä vaativana suuntana.

Henkilöstökoulutuksen epätasaisen jakautumisen vuoksi raportissa esitetään julkista aikuiskoulutusta kehitettäväksi niin, että se varmistaa kaikille mahdollisuuden koulutuksen vapaaseen valintaan.

Markkinavoimien raportti katsoo suuntaavan aikuiskoulutusta laaja-alaisesta koulutuksesta faktojen ja erityistekniikoiden oppimiseen, mikä vahvistaa instrumentaalista ja rationalistista lähestymistapaa tietoon. Demokratiaa vahvistavan koulutuksen, kulttuurisen osallistumisen ja kokonaisvaltaisen ja humanistisen lähestymistavan tietoon raportti katsoo olevan väistymässä. Siksi raportissa esitetään julkisen aikuiskoulutuksen ja erityisesti vapaan sivistystyön asemaa vahvistettavaksi.

Henkilöstökoulutuksessa raportti katsoo kilpailun olevan mahdollista, koska se on aikuiskoulutuksen tasa-arvotavoitteiden ulkopuolella. Valtion tukemassa koulutuksessa kilpailua ei pidetä hyödyllisenä. Raportissa esitetään, että julkisesti tuetun koulutuksen eri tarjoajien tavoitteet ja kohderyhmät on määriteltävä selvästi ja samalla on edistettävä tarjoajien välistä yhteistyötä, jotta resurssit tulevat käytetyksi rationaalisesti ja aikuiskoulutuksen yleistavoitteiden mukaisesti.

Raportissa heitetään ilmaan myös kysymys, tulisiko valtion kuitenkin vaikuttaa henkilöstökoulutukseen ja miten? Vastausta ei kuitenkaan anneta, koska asia sisältyy parhaillaan istuvan komitean asialistalle.

Etäopetuksen raportti toteaa aikaisemmin jääneen heikosti kehittyneeksi, koska koulutusta pyrittiin hajauttamaan mahdollisimman pitkälle. Nyt nähdään, että aikuiskoulutuksen uudet haasteet edellyttävät koulutuksen saavutettavuuden lisäämistä myös etäopetuksen keinoin.

\section{Aikuiskoulutuksen muutosstrategiat}

Raportin toimenpideosassa esitetään pitkäkestoisen aikuiskoulutuksen kehittämisohjelman käynnistämistä. Ohjelma muodostuisi kolmesta kolmivuotisesta suunnittelujaksosta.

Ensimmäisellä jaksolla tehtäisiin laajat kartoitukset koko aikuisväestön ja sen eri alaryhmien tarvitsemista perustiedoista ja -taidoista sekä yhteiskunnallisten oikeuksien toteutumista rajoittavia puutteita omaavien ryhmien suuruudesta, selkeytettäisiin julkisen aikuiskoulutuksen eri tahojen toimenkuvat ja yhteistyömuodot, kehitettäisiin laajasti etäopetusta sekä muodostettaisiin aikuiskoulutukseen erilaisia evaluointimalleja.

Toisella jaksolla ryhdyttäisiin kartoitusten perusteella tasaisesti kasvattamaan yleistä taitotasoa kohottavaa aikuiskoulutusta, kehitettäisiin aikuiskouluttajakoulutusta ja muokattaisiin opintotuen saantiehtoja niin, että ne edistäisivät hakeutumista perustaitoja kehittävään koulutukseen.

Kolmas jakso keskittyisi aikuiskoulutuksen määrään, rakenteeseen ja kohdistumiseen pitkällä tähtäimellä.

\section{Arvio raportista}

Ruotsin yhteiskunnallisen perinteen mukaisesti raportissa nähdään koulutuksellisen epätasaarvon yhtenä keskeisenä ilmentymänä koulutusjärjestelmässä saadun koulutuksen pituudessa ilmenevät erot. Suomessa käydyssä keskustelussa on tuotu esiin, että vähän koulutetut eivät ole yhtenäinen ryhmä. Muodollisesti vähälle koulutukselle jääneet henkilöt ovat voineet kehittää itsenään työssä tai kansalaisena muulla tavoin. Toisaalta kauan sitten suoritetut kouluopinnot eivät takaa, että tiedot ja taidot tosiasiassa olisivat ajan tasalla.

Sama perinne korostaa aikuisten perustaitojen keskeisyyttä. Suomalainen Väestön koulutus 2000 -mietintö esitetään raportissa yhtenä esimerkkinä muunlaisista lähestymistavoista. Tässä mietinnössä kuten yleensä suomalaisessa keskustelussa viime aikoina ovat korostuneet aikuisväestölle tarjottavat mahdollisuudet ammatillisen koulutuksen hankkimiseen.

Julkinen aikuiskoulutusjärjestelmä nähdään raportissa omana alueenaan, jonka toiminnalliset yhteydet työelämään ovat vähäiset. Suomessa on viime aikoina korostettu kaikkien aikuiskoulutusta järjestävien oppilaitosmuotojen velvollisuutta toimia yhteistyössä työelämän kanssa ja tarjota palveluksiaan myös yrityksille ja julkisyhteisöille.

Selvin ero raportissa ilmenevän ajattelun ja 
suomalaisten näkökantojen välillä on kuitenkin aikuiskoulutuksen ohjausmalleissa. Raportti korostaa voimakkaan keskusohjauksen merkitystä tarkoituksenmukaisesti toimivan aikuiskoulutusjärjestelmän aikaansaamisessa. Kilpailun nähdään johtavan resurssien hukkakäyttöön ja päämäärätietoisuuden katoamiseen. Suomessa katsotaan, että keskusohjattu aikuiskoulutus ei kykene vastaamaan riittävän joustavasti aikuiskoulutuksen monimuotoiseen ja nopeasti muuttuvaan kysyntään. Vain kilpailua luomalla saadaan koulutuksen tarjontaan riittävää eloa.
Ohjausajattelun eroja heijastelee myös raportin toimenpideohjelma. Se perustuu suurten koulu-uudistusten suunnittelumallille: laaja kokonaisuudistus suunnitellaan ensin valmiiksi ja valittua mallia lähdetään sitten viemään käytäntöön. Suomessa on valittu toinen strategia. Aikuiskoulutuksen kehittämiselle on määritelty painopisteet ja etsitty niiden mukaisesti aikuiskoulutuksen eri osa-alueilta konkreettisia, erillisinäkin toteutettavissa olevia toimenpiteitä, joita sitten on lähdetty viemään eteenpäin.

JORMA AHOLA 